\title{
Developing a Commercial Ethics Framework for Analysing Marketing Campaigns
}

\author{
Vasco Ribeiro Santos, ISLA Santarém, Portugal \& CiTUR, Portugal \\ (iD https://orcid.org/0000-0002-3535-9377 \\ Tiago Ferreira Vitorino, ISLA Santarém, Portugal \\ Álvaro Lopes Dias, Universidade Lusófona de Humanidades e Tecnologias, Portugal \\ (iD) https://orcid.org/0000-0003-4074-1586 \\ Domingos Martinho, ISLA Santarém, Portugal \\ Bruno Barbosa Sousa, Polytechinc Institude of Cávado and Ave, Portugal \& CiTUR, Portugal \\ iD https://orcid.org/0000-0002-8588-2422
}

\begin{abstract}
This study integrates the relationship of business ethics in marketing campaigns and the importance of the repercussion on organizational performance with the aim of creating a guide of business ethics in marketing campaigns for small and medium enterprises (SMEs). This guide allows SMEs to analyse their ethical dimension as well as to raise awareness and instill commercial ethics actions in the marketing campaign common practices in organisations. The qualitative methodology has been applied, and the proposed theoretical model uses a set of dimensions of ethics, commercial ethics, codes of conduct, marketing, and marketing campaigns to analyse the relationship of commercial ethics with marketing campaigns and its influence on organisations. The result demonstrates the influence of commercial ethics on advertising actions that, when applied positively, enable and promote the brand image, thus contributing to the organizational performance.
\end{abstract}

\section{KEYWORDS}

Commercial Ethics, Framework Marketing Campaigns, Organizational Performance

\section{INTRODUCTION}

With the growing concern of companies, forums dedicated to the promotion of ethical practices and models, studies on the subject, the introduction of disciplines in various courses have emerged around the world, which naturally led to the development of the area of business ethics (da Costa et al. 2020; Robertson, Voegtlin \& Maak, 2017). For various reasons, business ethics has decisively influenced companies' behavior and respective communication actions, particularly marketing campaigns (Jones, Parker \& Ten Bos, 2005). In a society where advertising and brand notoriety and experience are crucial to the SME's image (Ferrell, et al., 2019; Pina \& Dias, 2020), consumer demand is constant 
and the community's attention to ethical issues is more visible, companies have been forced to change their behaviors and attitudes to ensure a responsible commitment to the community. However, there are still organisations that in their marketing campaigns focus simply on selling their product and attracting the consumer by not respecting ethical principles (Islam, 2020), making the campaigns too aggressive, biased, negligent and sometimes even fraudulent (Dias et al., 2013). Apart from these improper behaviours, organisational commitment is sometimes very delicate or non-existent, there are no institutional norms to direct behaviour, human and material resources and investment is low and not profitable (Duque et al., 2020).

It is therefore essential to approach business ethics in company marketing campaigns in order to understand how the dimensions of ethics relate to types of marketing campaigns and the extent to which they influence the performance of the organisation and the return they can bring at various levels (de Bakker, Rasche \& Ponte, 2019). The main objective of this study is to elaborate a guide of commercial ethics in marketing campaigns for SMEs, to evaluate their actions and instill practices conducive to the understanding of the subject, thus properly guiding marketing campaigns according to commercial ethics.

Thus, this study aims to respond to a set of specific objectives, namely: (i) to evaluate the strategic motivations that justify the integration of commercial ethics in marketing campaigns; (ii) to identify types of campaigns; to evaluate the implicit advantages of adopting commercial ethics in marketing campaigns; (iii) to identify the benefits that their adoption brings to the company, stakeholders and society; (iv) to promote the practice of ethical actions in marketing campaigns by organizations and contribute to a greater understanding of the subject.

Thus, to achieve these objectives it will be necessary to define the concepts of ethics, commercial ethics, codes of ethical conduct, marketing, marketing campaigns and SMEs based on the thought of authors who have devoted attention to the themes, the evolution of concepts and the multiple visions defended in academic and business circles over the last decades, seeking a coherent interpretation of the concepts that will allow them to operate in the study and adopt commercial ethics in marketing campaigns of SMEs; identifying the typology and characterization of marketing campaigns; analyzing the process of implementing commercial ethics in marketing campaigns; creating a model guide that will allow implementing the proposed problem.

The article is structured in four parts, such as the literature review on ethics, business ethics, codes of ethical conduct, marketing, marketing campaigns and SMEs, the research methodology (section 3), the development of the guide (section 4). Finally conclusions, managerial implications for commercial management, as well the limitations and suggestions for future research.

\section{THEORETICAL BACKGROUND}

\subsection{Ethics and Business Ethics}

Starting by analysing ethics, this is a complex area as there is no absolute agreement on what establishes ethical conduct; however, each individual thinks about his or her ethical position and the influence this has on their behaviour (Crowther \& Aras, 2008). In its etymological sense, ethics is a word that derives from the Greek ethos and refers to both the way of being and the character, from which human acts come, such as customs, habits, and the way of acting that indicate the conduct of a certain person (Dias, 2004). Ethics has as its object of study the human being and his fundamental values such as equality or happiness, but also that which opposes him, which is, what he must do or avoid, regardless of the personal, social or organizational benefits associated (Dias et al., 2013). According to Vickers (2005), ethics is a set of moral principles or values of society, which indicate what is right or wrong, good or bad, influencing the way individuals act. Chiavenato (2003) makes the link between ethics and business ethics by stating that ethics constitutes the set of moral values or principles that define what is right or wrong for a person, group or organisation. 
With its growth, business ethics has been interpreted as more than just making profit and enforcing the law alone (Neves, 2008). According to Keller-Krawczyk (2010) business ethics are all ethical principles identified and implemented in business activity to ensure that the interests of all stakeholders are respected. Business ethics affect the decision making process, constituting a regulatory method of ethical values and principles in accordance with the social and cultural values in which the company is involved, contributing to the reputation and organizational results and thus favoring all stakeholders of the organization (de Bakker, Rasche \& Ponte, 2019; Rego et al, 2006). Business ethics demonstrate how an organisation should act, taking into account honesty, trust, respect and fairness in all circumstances (Crowther \& Aras, 2008). However, it is during the last decades that the subject has become the subject of unprecedented attention from academics, entrepreneurs, politicians and society (Almeida, 2007). Ethics in business management is developing to stop being only normative by understanding a series of ethical dimensions (legality, humanity, transparency, social responsibility, values, organisational culture and sustainability) (Dias et al., 2020), which due to their complexity are interconnected in the definition of their objectives, committing themselves to society (Coimbra, 2007). The organizational world is in persistent change, particularly in the field of ethics, where standards are transformed, conducts are rethought and new challenges arise in the structure of the company. It is up to the bosses, managers and marketers to develop differentiated strategies to meet the demands of the market (Costa, 2013).

Table 1 shows the origin of business ethics motivations and the level of analysis of their implications.

Table 1. Origin of business ethics motivation

\begin{tabular}{|l|l|l|l|}
\hline & & \multicolumn{2}{|c|}{ Origin } \\
\hline \multirow{2}{*}{$\begin{array}{l}\text { Level of } \\
\text { Analysis }\end{array}$} & Contextual & \begin{tabular}{l}
\multicolumn{1}{c|}{ Internal } \\
Integration (Promoting acceptance, \\
visibility, recognition and value)
\end{tabular} & $\begin{array}{l}\text { Legitimacy (Legality, transparency, } \\
\text { trust, social responsibility) }\end{array}$ \\
\cline { 2 - 4 } & Organisational & $\begin{array}{l}\text { Social Awareness (Organisational } \\
\text { culture, motivation, values, principles, } \\
\text { greater efficiency) }\end{array}$ & $\begin{array}{l}\text { Market Strategic Motivation, greater } \\
\text { efficiency, adaptation) }\end{array}$ \\
\hline
\end{tabular}

Source: Adapted from Almeida (2007)

Organizations must therefore adapt ethical strategies to optimize organizational performance, based on individual and collective responsibility, based on and defended by universal principles (Days, 2014). From the perspective of Costa (2013), business ethics are increasingly valued and many consumers take ethical attitudes of the organization into account in their purchasing decision, this concern contributes to organizations having new perspectives and developing new strategies of action for ethical consumption that now arise in business and in the characterization of ethical consumers.

Ethical consumption develops towards sustainability, giving rise to a new term, sustainable consumption. The growing proliferation of ethical culture has attracted the interest of organisations seeking to meet the needs of individuals and as such could not reject this new business trend as well as a new consumer segment (Carrington, Neville, \& Whitwell, 2010). Tallontire, Rentsendorj and Blowfield (2001) identify three types of consumers: (1) activists, (2) ethical and (3) semi-ethical. Activists, the main advocates of ethical consumption, want to know about the actions in order to persuade other consumers to know and try ethical products; ethical consumers want to know more about the ethical products they buy; and finally, semi-ethicals who consume irregular ethical products can be influenced to buy more. 
Organisational ethics and social responsibility are no longer seen as a burden and obligation, but as a beneficial and profitable investment, with short and long term repercussions (Costa, 2013). The organisation must re-establish its organisational culture so that it is in line with the market and social standards of ethical conduct (Pride \& Ferrell, 2016). An ethical organisation must have, even without certainties of success, certain structures, processes and measures for measuring ethical performance that influence the application of attitudes and ethical conduct (Svensson \& Wood, 2011). Second (Dias, 2014), organisations must develop an ethical programme, which translates the expected behaviour of all employees, if they really want to encourage ethical behaviour, even though they do not solve all the problems they help to prevent negative and unacceptable behaviour in the organisational context.

Codes of conduct are important for the implementation of business ethics in organizations, an added value that must be implemented by companies in the pursuit of their objectives according to the ethical dimensions. These, due to the constant evolution and influences of the areas of business activity, should be reviewed periodically in order to identify opportunities and eliminate weaknesses in the ethical principles of the organization.

\subsection{Marketing}

Etymologically, marketing is a word dating from the 16th century, of English origin and derived from the verb to Market, in the sense of "to negotiate in the market" and has three major axes: the achievement of the client; the inclusion of the organization and the execution of objectives (Sobral \& Peci, 2008). Marketing is a social and management process by which individuals and organizations get what they need and want, through the creation and exchange of value with others, to attract new clients by promoting value and maintaining current clients by offering satisfaction (Kotler \& Armstrong, 2012).

For Lindon et. al. (2013), marketing is the pooling of resources that an organisation has at its disposal to promote behaviour favourable to the achievement of its objectives. Marketing that was essentially transactional, with each purchase viewed in an isolated transaction, evolved into relational marketing, where the needs and consumption of each client are studied and monitored over a given period of time. This type of particular and exclusive marketing, called customer relationship management, arises to meet the gradual concerns of organisations in building customer loyalty and creating value.

\subsection{Marketing Campaigns}

Advertising is one of the integral parts of an organisation's marketing, it is usually defined as a paid, purposeful and interested communication in a presentation to promote the organisation's ideas, goods or services by an identified sponsor with the aim of informing and persuading, inducing the need to purchase and obtain satisfaction to reach a certain target audience within a period of time (Kotler \& Armstrong, 2012). Advertising is one of the most penetrating and powerful phenomena in the world, a persuasive force that influences mentality and behaviour (Sasu, Pravat, \& Luca, 2015).

Organizations that do not develop strategies and programs to incorporate ethics and social responsibility can be punished in their marketing performance, perceived by bad publicity or potential costs associated with legal violations, which when made public affect the organization's image (Pride \& Ferrell, 2016). Organisations are less and less able to cover up negative situations, whether intentional or accidental, as scandals are reported and disseminated on social networks, leading to public demonstration (Costa, 2013).

To promote socially responsible and ethical behavior, marketers are required to be familiar with various types of ethical issues in order to keep pace with changes and trends in society, while at the same time achieving organizational goals in order to determine new consumer behavior and predict the long-term effects of their decisions. Therefore, the greater the consequences associated with a problem, the more likely it is that an ethical decision will be recognized and made to resolve it (Pride \& Ferrell, 2016). 
Good advertising seeks to influence the individual to choose and act rationally, while bad advertising seeks to institute the individual to take destructive actions for himself and society (Sasu, Pravat, \& Luca, 2015). The relationship between advertising and ethics can be observed according to the persuasion of advertising, decession, suffering and promises that cannot be kept (Siham, 2013).

\subsection{Small and Medium-Sized Enterprises (SMEs)}

According to the National Statistical Institute (INE,2020), an SME is the category that aggregates micro, small and medium-sized enterprises with fewer than 250 people and an annual turnover of less than EUR 50 million or an annual balance sheet total of up to EUR 43 million. A micro-enterprise is defined as having up to 10 employees and an annual turnover or balance sheet total of up to EUR 2 million. A small enterprise is defined as having less than 50 employees and an annual turnover or annual balance sheet total of up to ?10 million (INE, 2020). SMEs are a pillar in the business structures of European economies because of their high representativeness. They are the main drivers of job creation, growth opportunities and social stability (European Union, 2015).

By engaging with educational institutions where they gain knowledge of new production, innovation and marketing processes (Pinheiro et al., 2020), national SMEs evolve, become increasingly strong as they seek to foster competitiveness, innovation, employment, and thus are willing to take risks in business internationally, assuming an increasing importance in the economy and emphasizing their role in the business structure of the country (IAPMEI, 2020).

\section{METHODOLOGY}

For the development of the work it was fundamental to review the literature on concepts related to the theme to obtain knowledge about the relationship between business ethics and marketing campaigns and verify whether the perception of the facts is in accordance with reality, in order to allow greater understanding and depth in the analysis in a current organizational context contributing to the structure and composition of the final objective, the guide.

To test the model, in-depth interviews with a group of 14 SME marketing managers were used. The results of the interviews were subject to content analysis and compared with the categories obtained in the literature review. Finally, the results were analysed by three academics who validated the final structure.

In this way, the analysis of the methodology adopted in this research will include the conceptualization of the study, the application of business ethics in marketing campaigns according to the problems, objectives and organizational performance, the conceptual model of business ethics is presented, the identification of methods and techniques for the pursuit of the model to guide, sensitize and instill ethical commercial actions in marketing campaigns of SMEs.

The structure and composition of the development of the Business Ethics Guide for SME Marketing Campaigns comprises six sections, are as follows: (1) diagnosis of SMEs; (2) internal business ethics in SMEs; (3) external business ethics in SMEs; (4) 4Ps of Business Ethics; and (5) definition of KPIs in business ethics campaigns.

\section{RESULTS - DEVELOPMENT OF THE BUSINESS ETHICS FRAMEWORK FOR SME MARKETING CAMPAIGNS}

After explaining the regulations, principles and techniques applicable to marketing campaigns according to commercial ethics, SMEs should apply diagnostic methods to check the level of ethics in the organisation in marketing campaigns in order to check whether they are complying or whether there is a need to make adjustments according to their strategy. 


\section{Identification}

Any company must initially clarify its identity in concrete terms. To do so, it must define its mission, explain the reason for the company's existence; the vision, what projection it intends to achieve; and, finally, the strategic values and principles for the company. Only after the identification of the mission, vision and values should the goals and aspirations of the company and the organisational culture be defined, which guide the strategies to be used to achieve the objectives and add value to all stakeholders in the business environment. In this way, the company is the foundation on which ethical and responsible action is then exercised on a daily basis in accordance with the law and its code of ethical conduct. Communication, information and training on ethical conduct are fundamental for the code of ethics to be shared by all and seen as a commitment and pillar of the company's actions.

\section{Integration}

With integration, SMEs must disseminate and promote their identity, which defines their organisational culture, to the employees of the organisation and at all organisational levels, in order to involve and boost strategic policies and in accordance with business ethics. Initially the organisational identity and culture should only be shared with the company's employees, customers, investors, suppliers or others close to them, in order to perceive a first reaction and possible suggestions. In a second moment, the organization should then spread widely among the other stakeholders already with the changes if necessary. The more integrated it is with the stakeholders' opinion, the more likely it is that the stakeholders will meet the assumed objectives and the consequent success of the company. The company must work daily with employees, maintain open communication and promote discussion, creativity and critical awareness so that, regularly, there is a relationship between the identity and organisational culture with the tasks so that the company can assess how it fits in with the descriptions of the company's work, its hiring practices or the development of products and services. Diversity and inclusion should also be understood as relevant elements of improvement, development, learning and valorisation of the company by promoting in the organisation the coexistence with employees from various origins and with different differences. With these conducts the motivation of employees is enhanced by making them feel that they are part of the company's performance, that they influence and are influenced by it. The commitment and commitment of employees are determining factors for the growth and sustainability of the company by ensuring added value for the company. Professional recognition and appreciation should also be promoted by the company by pursuing programmes that plan and advise careers. The attribution of compensations or benefits should be based on the evaluation of skills, performance and ethical conduct. Where practices do not correspond to what is required by the organisation, the necessary changes should be implemented to promote a good working environment and achieve the desired harmony and full integrity.

\section{Strategy}

SME should also draw up its business plan to frame possible strategic actions in a manner consistent and integrated with business ethics towards its objectives and showing the existing opportunities and challenges to be faced. In this way, it is essential for the company to have a business plan because internally it guides its strategy and externally it presents to investors and stakeholders the actions to develop inherent to the business opportunities it pursues. In the development of the plan the company must involve and share with its employees and stakeholders. It must also regularly analyze and evaluate and frame new objectives and challenges or adapt.

With business policies SMEs define the main policies in the field of business ethics, namely environment and sustainability policies and corporate social responsibility. With environment and sustainability, SMEs should actively collaborate on environmental policies and good practices in order to reduce environmental impact, promote and adapt alternative and sustainable practices such as circular economy, calculate the ecological footprint regularly, use intelligent systems for efficient 
consumption, use renewable sources, encourage the use of alternative and environmentally friendly transport and promote reduction, reuse and recycling. In corporate social responsibility, SMEs define policies and good practices that support and promote social programs and initiatives in the communities where they operate and partnerships with entities in order to deliver community benefits adding value to the public cause.

\section{Training}

SMEs should consider continuous training and invest in this area in order to provide employees with greater skills, including ethical skills, and knowledge fundamental to enhancing their employability, career progression and company growth. A training policy should lead to a culture of quality and productivity that seeks opportunities to improve performance by promoting ambition, creativity and individual initiative. In addition to the benefits for employees, training is fundamental to the transformation and innovation of the company by allowing new working methods to be applied.

\section{Equal Opportunities}

The firms should promote efforts to ensure full equality of opportunity among all employees and with all stakeholders by persistently combating any form of discrimination and promoting diversity and inclusion and spreading freedom of opportunity and treatment between men and women. To this end, it must recruit and select its employees according to technical criteria and ethical principles.

\section{Safety, Hygiene, Health and Well-being at Work}

With safety and hygiene, SMEs should promote actions such as healthy working habits and evaluate and prevent risks within the professional activity. In health and well-being companies promote actions to prevent diseases in the professional context, promote health plans, screening, healthy lifestyles and practices to reconcile work and family life. By applying these actions, companies demonstrate their importance and concern for employees and an ethical business conduct.

\section{Control}

The firm, with its constant evolution and transformation in the context of its activities, both local and global, needs to review its conduct and practices, and if necessary even its identity, so that it always contemplates its objectives in accordance with the new challenges. Therefore, it should be considered a regular evaluation of its organizational performance so that its behaviors correspond to the values that guide its company and in accordance with business ethics. For the regular evaluation to be successful, a specific area of management of the whole process must be created, such as a team or a system, from its conception to its implementation and monitoring, with the responsibility of leading, dynamising and analysing the statistical data obtained. In addition, tools should be created to report incorrect behaviour, which is not in accordance with the organisational practices.

\section{Stakeholders}

SMEs must identify all stakeholders and classify them according to their importance to the company, respecting them in order to frame the different relationships. Thereafter the company must share its identity, strategic objectives and ethical practices involving the stakeholders through regular open communication in order to assume its commitments and demand ethical criteria. They must also have tools to report behaviours that do not correspond to those required by the company.

Companies must compete with each other fairly, accepting and respecting the rules of the market economy in which they operate. The company's actions must renounce false practices that deceive the competition. Its conduct must be governed by principles of transparency and business ethics, focused on the competitive valuation of the performance, merit and quality of its products and services. They must also initiate efforts to develop partnerships. 


\section{Communication}

Using promotion and publicity, SMEs should implement communication policies that are in line with existing legislation, are honest and truthful in order to respect values and principles in accordance with business ethics and organisational culture. The various promotion and advertising actions should exclude any conduct that causes doubt in their perception and that promotes information that may lead to discriminatory factors, and promote practices that respect customers' freedom of choice and scrupulously respect customers' privacy and rights. Social and environmental causes should also be supported and promoted by business. Whenever they develop campaigns, they should also inform employees and stakeholders as well as the impact they are having on the organisation.

\subsection{Analysing Business Ethics Framework in SME Marketing Campaigns}

This identifies the following methodologies that identify the dimensions of business ethics in the company and actions that allow the analysis and diagnosis of imposed ethical practices

\subsection{KPI Definition in Business Ethics Campaigns}

KPI - key performance indicators, of commercial ethics in marketing campaigns, the management tools to perform the measurement and consequent level of ethical performance and success of the objectives set by the company - are defined. The key indicators for assessing the performance of business ethics in marketing campaigns should include the following areas: identification; integration; data collection and analysis; e-commerce; promotion and advertising; value chain; customer relationships; ethical, social and sustainable practices; productivity; corporate responsibility; 4Ps of business ethics.

After identifying the crucial areas and actions inherent to them, SMEs to evaluate the performance of business ethics in marketing campaigns should implement methods that indicate performance, such as: matrices; rules and manuals; code of ethical conduct; reports; statistical data; audits; surveys; policies; partnerships; contacts with customers; training; communications; ethical competencies of employees; programs and practices that promote business ethics; recognition and valorization practices; ethical budgeting; marketing campaigns; creativity; control and evaluation systems; balanced scorecard; triple bottom line. The indicators can be classified according to quality, capacity, productivity or strategy.

\section{CONCLUSIONS}

\subsection{Theoretical Contributions}

It was concluded that there are several definitions for ethics, having in common some elements such as the principles that guide ethical conduct or the distinction between right and wrong. As for business ethics, although it also depends on the employee's commitment, it is influenced by several internal and external factors, and it is essential for the company to foster an environment that promotes ethical behavior and concrete practices. The code of ethical conduct proves to be a crucial tool for the company to define the expected behaviors of its employees and internal rules that meet its objectives and organizational culture in accordance with ethics. In marketing, we can understand its enormous evolution and the growing importance in the organization's strategy, particularly in the relationship with the client, as well as the enormous complexity and constant innovation. In marketing campaigns one understands the various constraints that influence their action, the fundamental principles that must be fulfilled in the campaigns and the primary role of marketers. Finally, in the SMEs its characteristics and the central importance for the Portuguese economy were verified.

With this research, the various influences and motivations for SMEs to implement ethical practices in their actions are perceived by the advantages and benefits they provide. With the guide, SMEs have a tool to evaluate the level of business ethics and test the impact and importance for marketing campaigns, demonstrating the pillars of action for the company to have a full business ethics conduct. 
Table 2. Business ethics framework in SME marketing campaigns

\begin{tabular}{|c|c|c|c|c|c|c|}
\hline \multirow{3}{*}{ AREAS OF ANALYSIS } & \multicolumn{5}{|c|}{ ASSESSMENT CRITERIA $(*)$} & \multirow{3}{*}{ Scoring } \\
\hline & \multirow{2}{*}{$\begin{array}{c}\begin{array}{c}\text { No } \\
\text { development }\end{array} \\
0\end{array}$} & \multirow{2}{*}{$\begin{array}{c}\begin{array}{c}\text { Incipient } \\
\text { development }\end{array} \\
1\end{array}$} & \multirow{2}{*}{$\begin{array}{c}\begin{array}{c}\text { Partial } \\
\text { development }\end{array} \\
2\end{array}$} & \multirow{2}{*}{$\begin{array}{r}\begin{array}{r}\text { Advanced } \\
\text { Development }\end{array} \\
3\end{array}$} & \multirow{2}{*}{$\begin{array}{c}\begin{array}{c}\text { Full } \\
\text { Development }\end{array} \\
4\end{array}$} & \\
\hline & & & & & & \\
\hline \multicolumn{6}{|c|}{ Internal Areas } & \\
\hline \multicolumn{7}{|c|}{ 1. Identification } \\
\hline \multicolumn{7}{|l|}{ 1.1 Mission, vision and values } \\
\hline \multicolumn{7}{|l|}{ 1.2 Strategic objectives } \\
\hline \multicolumn{7}{|l|}{$\begin{array}{l}\text { 1.3 Defining ethical business conduct in } \\
\text { marketing campaigns }\end{array}$} \\
\hline \multicolumn{7}{|l|}{$\begin{array}{l}\text { 1.4 Contextualize RGPD and defining } \\
\text { concrete practices }\end{array}$} \\
\hline \multicolumn{7}{|l|}{$\begin{array}{l}\text { 1.5 Contextualize competition law and } \\
\text { defining concrete practices }\end{array}$} \\
\hline \multicolumn{7}{|l|}{$\begin{array}{l}\text { 1.6 Contextualize Legal Regime Unfair } \\
\text { Practices and Defining Concrete Practices }\end{array}$} \\
\hline \multicolumn{7}{|l|}{$\begin{array}{l}\text { 1.7 Contextualize Sociocultural Principles } \\
\text { and Defining Concrete Practices }\end{array}$} \\
\hline \multicolumn{7}{|l|}{$\begin{array}{l}\text { 1.8 Contextualize Organizational Principles } \\
\text { and define concrete practices }\end{array}$} \\
\hline \multicolumn{7}{|l|}{ 1.9 Define other concrete ethical practices } \\
\hline \multicolumn{7}{|l|}{ 2. Integration } \\
\hline \multicolumn{7}{|l|}{$\begin{array}{l}\text { 2.1 Sharing mission, vision, values and } \\
\text { strategic objectives by employees }\end{array}$} \\
\hline \multicolumn{7}{|l|}{$\begin{array}{l}2.2 \text { Integrating employees } \\
\text { - Digital presentation } \\
\text { - Company Guide } \\
\text { - Integration manual }\end{array}$} \\
\hline \multicolumn{7}{|l|}{$\begin{array}{l}\text { 2.3 Involving employees in the objectives } \\
\text { - Promote regular communication } \\
\text { - Promoting discussion, creativity and critical } \\
\text { awareness }\end{array}$} \\
\hline \multicolumn{7}{|l|}{$\begin{array}{l}\text { 2.4 Sharing the code of ethical conduct by } \\
\text { employees }\end{array}$} \\
\hline \multicolumn{7}{|l|}{ 2.5 Promoting diversity and inclusion } \\
\hline \multicolumn{7}{|l|}{ 2.6 Promoting a good working environment'. } \\
\hline \multicolumn{7}{|l|}{$\begin{array}{l}2.7 \text { Ensuring personal and professional } \\
\text { integrity }\end{array}$} \\
\hline \multicolumn{7}{|l|}{$\begin{array}{l}\text { 2.8 Promoting professional recognition and } \\
\text { enhancement }\end{array}$} \\
\hline \multicolumn{7}{|l|}{ 3. Data Collection and Analysis } \\
\hline \multicolumn{7}{|l|}{ 3.1 Assess and analyse employee performance } \\
\hline $\begin{array}{l}\text { 3.2 Evaluate and analyse the ethical } \\
\text { performance of employees }\end{array}$ & & & & & & \\
\hline 3.3 Assess and analyse company performance & & & & & & \\
\hline 4. Business Plan & & & & & & \\
\hline 4.1 Involving employees and stakeholders & & & & & & \\
\hline 4.2 Sharing with employees and stakeholders & & & & & & \\
\hline $\begin{array}{l}\text { 4.3 Define concrete practices to regularly } \\
\text { analyse and evaluate and frame new } \\
\text { objectives and challenges }\end{array}$ & & & & & & \\
\hline
\end{tabular}


Table 2. Continued

\begin{tabular}{|c|c|c|c|c|c|c|}
\hline \multirow{3}{*}{ AREAS OF ANALYSIS } & \multicolumn{5}{|c|}{ ASSESSMENT CRITERIA $(*)$} & \multirow{3}{*}{ Scoring } \\
\hline & \multirow{2}{*}{$\begin{array}{c}\begin{array}{c}\text { No } \\
\text { development }\end{array} \\
0 \\
\end{array}$} & \multirow{2}{*}{$\begin{array}{c}\begin{array}{c}\text { Incipient } \\
\text { development }\end{array} \\
1 \\
\end{array}$} & \multirow{2}{*}{$\begin{array}{c}\begin{array}{c}\text { Partial } \\
\text { development }\end{array} \\
2 \\
\end{array}$} & \multirow{2}{*}{$\begin{array}{c}\begin{array}{r}\text { Advanced } \\
\text { Development }\end{array} \\
3 \\
\end{array}$} & \multirow{2}{*}{$\begin{array}{c}\begin{array}{c}\text { Full } \\
\text { Development }\end{array} \\
4 \\
\end{array}$} & \\
\hline & & & & & & \\
\hline \multicolumn{6}{|c|}{ Internal Areas } & \\
\hline \multicolumn{7}{|c|}{ 1. Identification } \\
\hline \multicolumn{7}{|l|}{ 5. Enterprise policies } \\
\hline \multicolumn{7}{|l|}{$\begin{array}{l}\text { 5.1 Defining environmental policies and good } \\
\text { practice }\end{array}$} \\
\hline \multicolumn{7}{|l|}{$\begin{array}{l}5.2 \text { Calculate ecological footprint on a regular } \\
\text { basis }\end{array}$} \\
\hline \multicolumn{7}{|l|}{ 5.3 Reducing environmental impact } \\
\hline \multicolumn{7}{|l|}{$\begin{array}{l}5.4 \text { Promoting and adapting alternative and } \\
\text { sustainable practices }\end{array}$} \\
\hline \multicolumn{7}{|l|}{5.5 Using renewable or alternative sources } \\
\hline \multicolumn{7}{|l|}{$\begin{array}{l}5.6 \text { Encouraging the use of alternative means } \\
\text { of transport }\end{array}$} \\
\hline \multicolumn{7}{|l|}{ 5.7 Having a fleet of green vehicles } \\
\hline \multicolumn{7}{|l|}{ 5.8 Promoting reduction, reuse and recycling } \\
\hline \multicolumn{7}{|l|}{$\begin{array}{l}5.9 \text { Implementing policies and practices in the } \\
\text { circular economy }\end{array}$} \\
\hline \multicolumn{7}{|l|}{ 5.10 Defining policies and good practice } \\
\hline \multicolumn{7}{|l|}{$\begin{array}{l}\text { 5.11 Support and promote social programmes/ } \\
\text { initiatives in the communities where they } \\
\text { operate }\end{array}$} \\
\hline \multicolumn{7}{|l|}{$\begin{array}{l}5.12 \text { Making and promoting donations, } \\
\text { support and promote voluntary programmes }\end{array}$} \\
\hline \multicolumn{7}{|l|}{$\begin{array}{l}5.13 \text { To publicly and recognize employees for } \\
\text { voluntary work }\end{array}$} \\
\hline \multicolumn{7}{|l|}{$\begin{array}{l}5.14 \text { Developing corporate volunteering } \\
\text { actions and establish partnerships with other } \\
\text { entities }\end{array}$} \\
\hline \multicolumn{7}{|l|}{ 6. Training } \\
\hline \multicolumn{7}{|l|}{ 6.1 Promote formative actions regularly } \\
\hline \multicolumn{7}{|l|}{6.2 Promoting career progression } \\
\hline \multicolumn{7}{|l|}{$\begin{array}{l}\text { 6.3 Promoting ethical competence / } \\
\text { Rewarding ethical skills }\end{array}$} \\
\hline $\begin{array}{l}\text { 6.4 Promoting ambition/creativity/individual } \\
\text { initiative }\end{array}$ & & & & & & \\
\hline 6.5 Define budget for training actions & & & & & & \\
\hline 7. Equal opportunities & & & & & & \\
\hline $\begin{array}{l}\text { 7.1 Define and apply technical criteria and } \\
\text { ethical principles in recruitment and selectio }\end{array}$ & & & & & & \\
\hline $\begin{array}{l}7.2 \text { Promoting freedom of opportunity and } \\
\text { equal treatment for men and women }\end{array}$ & & & & & & \\
\hline 7.3 Promoting diversity and inclusion & & & & & & \\
\hline 7.4 Recognising and promoting employees & & & & & & \\
\hline 8. Safety, Hygiene, Health and Well-beir & Vork & & & & & \\
\hline 8.1 Promoting safety and hygiene at work & & & & & & \\
\hline 8.2 Promoting healthy work habits & & & & & & \\
\hline
\end{tabular}


Table 2. Continued

\begin{tabular}{|c|c|c|c|c|c|c|}
\hline \multirow{3}{*}{ AREAS OF ANALYSIS } & \multicolumn{5}{|c|}{ ASSESSMENT CRITERIA (*) } & \multirow{3}{*}{ Scoring } \\
\hline & \multirow{2}{*}{$\begin{array}{c}\begin{array}{c}\text { No } \\
\text { development }\end{array} \\
0\end{array}$} & \multirow{2}{*}{$\begin{array}{c}\begin{array}{c}\text { Incipient } \\
\text { development }\end{array} \\
1\end{array}$} & \multirow{2}{*}{$\begin{array}{c}\begin{array}{c}\text { Partial } \\
\text { development }\end{array} \\
2\end{array}$} & \multirow{2}{*}{$\begin{array}{c}\begin{array}{c}\text { Advanced } \\
\text { Development }\end{array} \\
3\end{array}$} & \multirow{2}{*}{$\begin{array}{c}\begin{array}{c}\text { Full } \\
\text { Development }\end{array} \\
4\end{array}$} & \\
\hline & & & & & & \\
\hline \multicolumn{6}{|c|}{ Internal Areas } & \\
\hline \multicolumn{7}{|c|}{ 1. Identification } \\
\hline \multicolumn{7}{|l|}{$\begin{array}{l}8.3 \text { Assessing and preventing occupational } \\
\text { risks }\end{array}$} \\
\hline \multicolumn{7}{|l|}{ 8.4 Prevention of occupational diseases } \\
\hline \multicolumn{7}{|l|}{ 8.5 Promoting health plans } \\
\hline \multicolumn{7}{|l|}{ 8.6 Promoting health screening } \\
\hline \multicolumn{7}{|l|}{ 8.7 Promoting healthy lifestyles } \\
\hline \multicolumn{7}{|l|}{$\begin{array}{l}\text { 8.8 Promoting practices to reconcile work } \\
\text { and family life }\end{array}$} \\
\hline \multicolumn{7}{|l|}{ 9. Control } \\
\hline \multicolumn{7}{|l|}{ 9.1 Periodic Review of Areas } \\
\hline \multicolumn{7}{|l|}{$\begin{array}{l}9.2 \text { Regularly assess the company's } \\
\text { performance in ethical practices }\end{array}$} \\
\hline \multicolumn{7}{|l|}{$\begin{array}{l}\text { 9.3 Sharing evaluation results and getting } \\
\text { feedback }\end{array}$} \\
\hline \multicolumn{7}{|l|}{$\begin{array}{l}9.4 \text { Creating a team or instrument responsible } \\
\text { for control }\end{array}$} \\
\hline \multicolumn{7}{|l|}{ External Areas } \\
\hline \multicolumn{7}{|l|}{ 10. Stakeholders } \\
\hline \multicolumn{7}{|l|}{ 10.1 Identify and classify } \\
\hline \multicolumn{7}{|l|}{$\begin{array}{l}\text { 10.2 Sharing the mission, vision, values and } \\
\text { strategic objectives }\end{array}$} \\
\hline \multicolumn{7}{|l|}{ 10.3 Regularly promote open communication } \\
\hline \multicolumn{7}{|l|}{ 10.4 Sharing the code of ethical conduct } \\
\hline \multicolumn{7}{|l|}{ 10.5 Respecting and framing relations } \\
\hline 10.6 Making commitments & & & & & & \\
\hline $\begin{array}{l}10.7 \text { Inform correctly about all products an } \\
\text { services }\end{array}$ & & & & & & \\
\hline $\begin{array}{l}\text { 10.8 Demanding ethical criteria from } \\
\text { suppliers }\end{array}$ & & & & & & \\
\hline 11. Competition & & & & & & \\
\hline 11.1 Respect for competitors & & & & & & \\
\hline 11.2 Loyalty and transparency & & & & & & \\
\hline 11.3 Defining partnerships & & & & & & \\
\hline 12. Electronic Commerce & & & & & & \\
\hline $\begin{array}{l}\text { 12.1 Means to respond immediately to } \\
\text { customers' requests }\end{array}$ & & & & & & \\
\hline $\begin{array}{l}\text { 12.2 Act and report in accordance with } \\
\text { existing rules and principles }\end{array}$ & & & & & & \\
\hline $\begin{array}{l}\text { 12.3 When a product is unavailable clearly } \\
\text { inform and propose alternatives }\end{array}$ & & & & & & \\
\hline 12.4 Developing a complaints service & & & & & & \\
\hline
\end{tabular}


Table 2. Continued

\begin{tabular}{|c|c|c|c|c|c|c|}
\hline \multirow{3}{*}{ AREAS OF ANALYSIS } & \multicolumn{5}{|c|}{ ASSESSMENT CRITERIA $(*)$} & \multirow{3}{*}{ Scoring } \\
\hline & \multirow{2}{*}{$\begin{array}{c}\begin{array}{c}\text { No } \\
\text { development }\end{array} \\
0\end{array}$} & \multirow{2}{*}{$\begin{array}{c}\begin{array}{c}\text { Incipient } \\
\text { development }\end{array} \\
1\end{array}$} & \multirow{2}{*}{$\begin{array}{c}\begin{array}{c}\text { Partial } \\
\text { development }\end{array} \\
2\end{array}$} & \multirow{2}{*}{$\begin{array}{c}\begin{array}{r}\text { Advanced } \\
\text { Development }\end{array} \\
3\end{array}$} & \multirow{2}{*}{$\begin{array}{c}\begin{array}{c}\text { Full } \\
\text { Development }\end{array} \\
4\end{array}$} & \\
\hline & & & & & & \\
\hline \multicolumn{6}{|c|}{ Internal Areas } & \\
\hline \multicolumn{7}{|c|}{ 1. Identification } \\
\hline \multicolumn{6}{|c|}{ INTERMEDIATE POINT - Level of business ethics in the company } & \\
\hline $\begin{array}{l}\text { Assessment scale of the level of business } \\
\text { ethics in the company }\end{array}$ & \multicolumn{6}{|c|}{$\begin{array}{l}\text { If between } 0 \text { and } 73 \text { points your level is Bad, you have to change your attitude urgently; Between } 74 \text { and } 146 \\
\text { is Sufficient, but you have to improve some areas; Between } 147 \text { and } 219 \text { is Good, good work but you can still } \\
\text { improve; Between } 220 \text { and } 292 \text { is Great, impeccable, still an example! }\end{array}$} \\
\hline \multicolumn{7}{|l|}{ 13. Promotion and Advertising } \\
\hline \multicolumn{7}{|l|}{$\begin{array}{l}13.1 \text { Promoting ethical practices in identity } \\
\text { marketing campaigns }\end{array}$} \\
\hline \multicolumn{7}{|l|}{$\begin{array}{l}13.2 \text { Promoting ethical practices in marketing } \\
\text { campaigns in accordance with honest and } \\
\text { truthful legislation and principles }\end{array}$} \\
\hline \multicolumn{7}{|l|}{$\begin{array}{l}\text { 13.3 Promoting marketing campaigns that } \\
\text { support social and environmental causes }\end{array}$} \\
\hline \multicolumn{7}{|l|}{$\begin{array}{l}13.4 \text { Inform employees and stakeholders of } \\
\text { the impact of marketing campaigns }\end{array}$} \\
\hline \multicolumn{7}{|l|}{$\begin{array}{l}13.5 \text { Promotion of practices that respect } \\
\text { customers' freedom of choice }\end{array}$} \\
\hline \multicolumn{7}{|l|}{ 13.6 Developing a complaints service } \\
\hline \multicolumn{7}{|l|}{$\begin{array}{l}13.7 \text { Setting the timing of marketing } \\
\text { campaigns }\end{array}$} \\
\hline \multicolumn{7}{|l|}{$\begin{array}{l}13.8 \text { Monitoring and evaluating the impact of } \\
\text { marketing campaigns }\end{array}$} \\
\hline \multicolumn{7}{|l|}{$\begin{array}{l}13.9 \text { Informing employees and stakeholders } \\
\text { of the development of marketing campaigns }\end{array}$} \\
\hline \multicolumn{7}{|c|}{ INTERMEDIATE POINT - Level of business ethics in marketing campaigns } \\
\hline $\begin{array}{l}\text { Result - Business ethics in marketing } \\
\text { campaigns }\end{array}$ & \multicolumn{6}{|c|}{$\begin{array}{l}\text { Between } 0 \text { and } 9 \text { points your level is Bad, you have to change your attitude urgently; between } 10 \text { and } 18 \\
\text { is Sufficient, but you have to improve some areas; between } 19 \text { and } 27 \text { is Good, good work but you can still } \\
\text { improve; between } 28 \text { and } 36 \text { is Great. }\end{array}$} \\
\hline FINAL SCORE - LEVEL OF BUSINES & CHICS & & & & & \\
\hline
\end{tabular}


In addition, it allows to understand which areas SMEs should improve their business ethics practices and how to implement and promote them in marketing campaigns, in order to boost organizational performance and results.

\subsection{Managerial Implications}

The literature review highlights the growing relevance of business ethics and marketing campaigns to the organisation, both internally and externally.

Companies should develop actions to implement and promote ethical behavior so as to safeguard socially responsible conduct and not compromise organizational performance. It is essential in any SME to have the commitment of managers and management in the management of ethical conducts, to monitor and motivate their inclusion and compliance according to the principles of the company which should be encouraged by daily and continuous practices. In addition, ethical performance measurement processes should be defined and their influence analysed to guide the implementation of attitudes and ethical and other practices with their stakeholders. This guide is a tool for SMEs to integrate ethics in the organizational culture and fundamentally in marketing campaigns and should be considered as a document with practical actions and methods that can be applied in the various areas of a company, a contribution to a better understanding of the subject and benefits of implementing business ethics in marketing campaigns, something that can be within the reach of any SME.

\subsection{Limitations of the Study and Future Research}

To talk about the application of the model in SMEs when developing and promoting marketing campaigns, this has not happened because of the pandemic crisis (Covid-19). To make the guide more practical to use, such as using an app that would make it easier to follow its implementation and also to understand the impact of this guide on small and medium-sized enterprises. 


\section{REFERENCES}

Almeida, F. (2007). Ethics and social performance of organisations: A theoretical model of analysis of cultural and contextual factors. Revista de Administração Contemporânea, 11(3), 105-125. doi:10.1590/S141565552007000300006

Argandoña, A. (2004). On Ethical, Social and Environmental Management Systems. Journal of Business Ethics, 51(1), 41-52. doi:10.1023/B:BUSI.0000032350.51151.0d

Arnsperger, C., \& Parijs, P. (2004). Economic and social ethics. Afrontamento Editions.

Cabral, Â. (2011). Emotional Intelligence and Ethics in Organizational Success. University of Coimbra.Carrigan, M., \& Attalla, A. (2001). The Myth of the Ethical Consumer - Do Ethics Matter in Purchase Behaviour? Journal of Consumer Marketing, 18(7), 560-578. doi:10.1108/07363760110410263

Carrington, M. J., Neville, B. A., \& Whitwell, G. J. (2010). Why Ethical Consumers Don't Walk Their Talk: Towards a Framework for Understanding the Gap Between the Ethical Purchase Intentions and Actual Buying Behaviour of Ethically Minded Consumers. Journal of Business Ethics, 97(1), 139-158. doi:10.1007/s10551010-0501-6

Chiavenato, I. (2003). Introduction to General Theory of Administration (7th ed.). Editora Campus.

Coimbra, M. A. (2007). The company has to know multiple dimensions of ethics. https://www.conjur.com. br/2007-mar04/empresa_conhecer_multiplas_dimensoes_etica

Costa, R. S. (2013). Reaction of Consumers to Ethical Behaviour of Enterprises. Faculty of Economics of the University of Porto.

Crowther, D., \& Aras, G. (2008). Corporate Social Responsibility. Book Boon.

da Costa, R. L., Dias, Á. L., Pereira, L., Santos, J., \& Miguel, I. (2020). The basis for a constructive relationship between management consultants and clients (SMEs). Business: Theory and Practice, 21(2), 666-674. doi:10.3846/btp.2020.11872

de Bakker, F. G., Rasche, A., \& Ponte, S. (2019). Multi-stakeholder initiatives on sustainability: A crossdisciplinary review and research agenda for business ethics. Business Ethics Quarterly, 29(3), 343-383. doi:10.1017/beq.2019.10

Dias, Á., Silva, G. M., Patuleia, M., \& González-Rodríguez, M. R. (2020). Developing sustainable business models: Local knowledge acquisition and tourism lifestyle entrepreneurship. Journal of Sustainable Tourism, 1-20. doi:10.1080/09669582.2020.1835931

Dias, Á. L., Varela, M., \& Costa, J. (2013). Excelência organizacional. Lisboa: bnomics.

Dias, M. (2004). Reflections on Ethics in the Daily Life of the Profession. Management and Development, 12, $81-103$.

Duque, L., Costa, R., Dias, Á., Pereira, L., Santos, J., \& António, N. (2020). New ways of working and the physical environment to improve employee engagement. Sustainability, 12(17), 6759. doi:10.3390/su12176759

Ethical Consumer. (2017). 20th Birthday. Obtido de Ethical Consumer: http://www.ethicalconsumer.org/ aboutus/20thbirthday.aspx

Ferrell, O. C., Harrison, D. E., Ferrell, L., \& Hair, J. F. (2019). Business ethics, corporate social responsibility, and brand attitudes: An exploratory study. Journal of Business Research, 95, 491-501. doi:10.1016/j. jbusres.2018.07.039

Freitas, C. (2012). Perception and Ethical Intent: Analysis of Ethical Positioning from a Consumer Perspective. Instituto Superior de Economia e Gestão.

Islam, G. (2020). Psychology and business ethics: A multi-level research agenda. Journal of Business Ethics, 165(1), 1-13. doi:10.1007/s10551-019-04107-w

Jones, C., Parker, M., \& Ten Bos, R. (2005). For business ethics. Routledge. doi:10.4324/9780203458457 
Keller-Krawczyk, L. (2010). Is Business Ethics Possible And Necessary? Economia e Sociologia, 3(1), 133-142.

Kotler, P. (1998). Marketing Management: Analysis, Planning, Implementation, and Control (6th ed.). Prentice Hall.

Kotler, P., \& Armstrong, G. (2012). Principles of Marketing. Pearson Prentice Hall.

Kotler, P. (2003). Marketing from A to Z: 80 concepts that every professional needs to know (6 $6^{\text {th }}$ ed.). Rio de Janeiro: Elsevier.

Lindon, D., Lendrevie, J., Lévy, J., Dionísio, P., \& Rodrigues, J. V. (2013). Theory and Practice of Marketing. Alfragide: Don Quixote Publications.

Massarutti, N. (2003). Business Ethics: Values and Norms that Define Organizational Identity. State University of Londrina.

Neves, J. (2008). Introduction to Business Ethics. Principia Editores.

Pina, R., \& Dias, Á. (2020). The influence of brand experiences on consumer-based brand equity. Journal of Brand Management, 1-17.

Pinheiro, J., Lages, L. F., Dias, Á., \& Preto, M. (2020). Fostering Knowledge Creation to Improve Performance: The Mediation Role of Manufacturing Flexibility. Business Process Management Journal, 26(7), 1871-1892. doi:10.1108/BPMJ-10-2019-0413

Pride, W. M., \& Ferrell, O. (2016). Marketing. Cengage Learning.

Rego, A., Cunha, M., Costa, N., Gonçalves, H., \& Cabral-Cardoso, C. (2006). Ethical and socially responsible management. Lisbon: HR.

Robertson, D. C., Voegtlin, C., \& Maak, T. (2017). Business ethics: The promise of neuroscience. Journal of Business Ethics, 144(4), 679-697. doi:10.1007/s10551-016-3312-6

Sasu, C., Pravat, G. C., \& Luca, F. A. (2015). Ethics And Advertising. SEA - Practical. Applied Sciences (Basel, Switzerland), 3(1), 513-518.

Siham, B. (2013). Marketing Mix - An Area of Unethical Practices? British Journal of Marketing Studies, 1(4), $20-28$.

Sobral, F., \& Peci, A. (2008). Administration: theory and practice in the Brazilian context. Pearson Prentice Hall.

Svensson, G., \& Wood, G. (2011). A conceptual framework of corporate and business ethics across organizations. Structures, processes and performance. The Learning Organization, 18(1), 21-35. doi:10.1108/09696471111095975

Tallontire, A., Rentsendorj, E., \& Blowfield, M. (2001). Ethical Consumers and Ethical Trade: A Review of Current Literature. Natural Resources Institute.

Vassilikopoulou, A., Siomkos, G., \& Rouvaki, C. (2008). The Ethical and Unethical Dimensions of Marketing. Management Review: An International Journal, 3(2), 49-60.

Vickers, M. (2005). Business Ethics and the HR role: Past, present and future. Human Resource Planning, 28(1), 26-32. 
Álvaro Dias is Professor of Strategy at Universidade Lusófona and ISCTE-IUL, both in Lisbon, Portugal. He got his Ph.D. in Management from Universidad de Extremadura, Spain, after an MBA in International Business. Professor Dias has over 24 years of teaching experience. He has had several visiting positions in different countries and institutions including Brazil, Angola, Spain, Poland, and Finland. He regularly teaches in English, Portuguese, and Spanish at undergraduate, master and doctorate levels, as well as in executive programs. Professor Dias has produced extensive research in the field of Tourism and Management, including books, book chapters, papers in scientific journals and conference proceedings, case studies, and working papers.

Bruno Sousa is a Professor in Polytechnic Institute of Cavado and Ave (IPCA, Portugal) Head of Master Program - Tourism Management - PhD Marketing and Strategy. He was Market Analist at Sonae Distribuição - Modelo e Continente, S.A. (2006 to 2009) and he was Marketing Assistant - Jornal O Jogo at Controlinveste (2005) - Best Paper Award in Strategic Marketing \& Value Creation (International Conference on Innovation and Entrepreneurship in Marketing and Consumer Behaviour 2020) Teaching Award of the School of Economics and Management of the University of Minho 2015/2016 - Best Thesis in Tourism Award - ICIEMC 2015 - Management Graduation, University of Minho Award - Best performance (2006) - Merit Scholarship for Students in Public Higher Education Awards of Merit Scholarship by University of Minho in 2001/02 - 2002/03 - 2003/04 Rresearch centre: CiTUR and Applied Management Research Unit (UNIAG). He is author or co-author of several papers and her research interests include tourism management, marketing and strategy. Editorial board member of several peer reviewed scientific journals and ad-hoc reviewer of several peer-reviewed scientific journals. Member of the scientific committee of several national and international congresses and conferences. 